\title{
Effects of luteinizing hormone on luteal cell populations in hypophysectomized ewes*
}

\author{
C. E. Farin†, T. M. Nett and G. D. Niswender \\ Animal Reproduction Laboratory, Department of Physiology, Colorado State University, \\ Fort Collins, Colorado 80523, USA
}

\begin{abstract}
Summary. To examine the effect of purified LH on development and function of luteal cells, 27 ewes were assigned to: (1) hypophysectomy plus $2 \mu \mathrm{g}$ ovine $\mathrm{LH}$ given i.v. at 4 -h intervals from Days 5 to 12 of the oestrous cycle (oestrus = Day 0; Group $\mathrm{H}+\mathrm{LH}$; $\mathrm{N}=7$ ); (2) hypophysectomy with no LH replacement (Group $\mathrm{N}-\mathrm{LH} ; \mathrm{N}=6$ ); (3) control (no hypophysectomy) plus LH replacement as in Group H+LH (Group S + LH; $\mathrm{N}=7$ ); (4) control with no LH treatment (Group $\mathrm{S}-\mathrm{LH} ; \mathrm{N}=7$ ). Blood samples were collected at 4-h intervals throughout the experiment to monitor circulating concentrations of LH, cortisol and progesterone. On Day 12 of the oestrous cycle corpora lutea were collected and luteal progesterone concentrations, unoccupied receptors for LH and number and sizes of steroidogenic and non-steroidogenic luteal cell types were determined. Corpora lutea from ewes in Group $\mathbf{H}-\mathbf{L H}$ were significantly smaller $(P<0.05)$, had lower concentrations of progesterone, fewer $\mathrm{LH}$ receptors, fewer small luteal cells and fewer non-steroidogenic cells than did corpora lutea from ewes in Group S-LH. The number of large luteal cells was unaffected by hypophysectomy, but the sizes of large luteal cells, small luteal cells and fibroblasts were reduced. LH replacement in hypophysectomized ewes maintained luteal weight and the numbers of small steroidogenic and non-steroidogenic luteal cells at levels intermediate between those observed in ewes in Groups L-LH and S-LH. In Group H + LH ewes, luteal and serum concentrations of progesterone, numbers of luteal receptors for $\mathrm{LH}$, and the sizes of all types of luteal cells were maintained. Numbers of small steroidogenic and non-steroidogenic cells were also increased by LH in hypophysectomized ewes.

In Exp. II, 14 ewes were assigned to: (1) sham hypophysectomy with no LH replacement therapy (Group S-LH; $N=5$ ); (2) sham hypophysectomy with $40 \mu$ g ovine $\mathrm{LH}$ given i.v. at 4-h intervals from Day 5 to Day 12 of the oestrous cycle (Group $\mathrm{S}+\mathrm{LH}$; $\mathrm{N}=5$ ); and (3) hypophysectomy plus $\mathrm{LH}$ replacement therapy (Group $\mathrm{H}+\mathrm{LH}$; $\mathrm{N}=4$ ). Experimental procedures were similar to those described for Exp. I. Treatment of hypophysectomized ewes with a larger dose of LH maintained luteal weight, serum and luteal progesterone concentrations and the numbers of steroidogenic and nonsteroidogenic luteal cells at control levels. Based on the results of the two experiments it is concluded that: (1) LH has important trophic actions for steroidogenic and nonsteroidogenic luteal cells; and (2) LH appears to be the only pituitary gonadotrophin required to maintain luteal function in ewes hypophysectomized during the oestrous cycle.
\end{abstract}

Keywords: sheep; LH; luteal cells

\footnotetext{
${ }^{*}$ Reprint requests to Dr G. D. Niswender.

$\dagger$ Present address: Department of Animal Sciences, University of Missouri, Columbia, Missouri 652I1, USA.
} 


\section{Introduction}

Based on previous studies, controversy exists over whether luteinizing hormone (LH) is the only pituitary gonadotrophin required for support of luteal development and function. Crude preparations of LH (Kaltenbach et al., 1968; Hixon \& Clegg, 1969) or prolactin (Hixon \& Clegg, 1969) were reported to maintain normal luteal function in hypophysectomized ewes. In ewes hypophysectomized approximately 50 days after hysterectomy, administration of both prolactin and $\mathrm{LH}$ was required for luteal maintenance (Denamur et al., 1973). Both LH and prolactin were also required for extension of the lifespan of corpora lutea in hypophysectomized, uterus-intact ewes from Days 12 to 20 after ovulation and to Day 25 of pregnancy (Schroff, 1971; Schroff et al., 1971). In the latter studies, however, corpora lutea in hypophysectomized ewes treated with $\mathrm{LH}$ alone were consistently maintained until Day 16 of the oestrous cycle. LH may therefore be sufficient to maintain luteal function throughout the normal oestrous cycle but both LH and prolactin may be necessary for extended luteal function.

Experiments designed to examine the roles of $\mathrm{LH}$ and prolactin in support of luteal function in pituitary-intact or hypothalamic-pituitary stalk-disconnected ewes support the conclusion that prolactin has little effect on luteal maintenance during the oestrous cycle (Karsch et al., 1971; McCracken et al., 1971; Niswender, 1974; Reimers \& Niswender, 1975). However, because prolactin cannot be entirely removed from the circulation in pituitary-intact ewes, the possibility remains that low levels of prolactin are critical for luteal function.

The corpora lutea of sheep are composed of steroidogenic and non-steroidogenic cell types (Warbritton, 1934; McClellan et al., 1975; O'Shea et al., 1979, 1980; Fitz et al., 1982). The two steroidogenic cell types, small and large luteal cells, differ morphologically, biochemically and functionally (O'Shea et al., 1979, 1980; Fitz et al., 1982; Rodgers et al., 1984). Small and large luteal cells from normally cyclic ewes have receptors for $\mathrm{LH}$ but differ in their response to $\mathrm{LH}$ for both production of progesterone (Harrison et al., 1987) and stimulation of adenylate cyclase (Hoyer \& Niswender, 1985). It has also been suggested that LH and/or hCG can promote differentiation of small steroidogenic luteal cells into large steroidogenic luteal cells (Gamboni et al., 1984; Farin et al., 1988).

The objective of the present research was to examine the effects of hypophysectomy and replacement with highly purified LH on maintenance of normal cellular development and luteal function in ewes.

\section{Materials and Methods}

Experiment I. Western range ewes predominately of Columbia and Corriedale breeding and demonstrating consecutive 16-17-day oestrous cycles were randomly assigned to one of 4 treatments: (1) hypophysectomy plus LH replacement (Group H+LH, N =7); (2) hypophysectomy with no LH replacement (Group $\mathrm{H}-\mathrm{LH}, \mathrm{N}=6$ ); (3) sham hypophysectomy plus LH replacement (Group $\mathrm{S}+\mathrm{LH}, \mathrm{N}=7$ ); (4) sham hypophysectomy without LH replacement (Group S-LH, $\mathrm{N}=7$ ). All ewes were laparotomized under pentobarbitol anaesthesia on Day 5 of the oestrous cycle (oestrus = Day 0 ) and the corpus luteum was marked with sterile charcoal. Immediately after laparotomy, a surgical plane of anaesthesia was maintained with halothane and each ewe was then subjected to its pre-assigned surgical treatment. Hypophysectomy was performed using the transnasal, transphenoidal approach (Clarke et al., 1983). Sham hypophysectomy consisted of all surgical procedures except the actual removal of the pituitary gland. Hypophysectomized ewes received $1 \mathrm{mg}$ bromocriptine at 06:00 $\mathrm{h}$ and 18:00 h throughout the treatment period to suppress secretion of prolactin from any residual pituitary fragments (Niswender, 1974). Replacement therapy with LH began at the time of laparotomy on Day 5 and continued until Day 12 of the oestrous cycle. To approximate endogenous $\mathrm{LH}$ pulses, as measured in a preliminary study (data not shown), $\mathrm{LH}$-treated ewes received $2 \mu \mathrm{g}$ purified ovine LH (NIH-oLH-S25) in $2 \mathrm{ml}$ sterile saline at 4-h intervals throughout the treatment period via indwelling jugular catheters. This dose was calculated to increase concentrations of $\mathrm{LH}$ to approximately $0.5 \mathrm{ng} / \mathrm{ml}$ serum after hormone administration. Based on radioimmunoassay, the LH preparation used in these studies contained $<0.1 \%$ by weight of prolactin and growth hormone and $<0.5 \%$ by weight of follicle-stimulating hormone and thyroid-stimulating hormone. 
Blood samples were collected through a second indwelling jugular catheter at 4-h intervals throughout the experiment and concentrations of cortisol were measured in samples taken daily at $06: 00 \mathrm{~h}$ to verify completeness of hypophysectomy. Concentrations of progesterone in serum were measured in samples collected daily at 06:00 or 10:00 h. On Days 10 or 11 of the treatment cycle, all LH-treated ewes were bled at 10 -min intervals for $5 \mathrm{~h}$ after administration of $\mathrm{LH}$ to determine the concentrations of $\mathrm{LH}$ in serum after treatment. Control ewes were bled at 10-min intervals for a 10-h period to monitor the height and frequency of endogenous pulses of LH. Blood samples were allowed to clot at room temperature for $4 \mathrm{~h}$ and stored at $4^{\circ} \mathrm{C}$ for $15 \mathrm{~h}$ before removal of serum.

On Day 12, ewes were laparotomized and marked corpora lutea were collected. Individual corpora lutea were decapsulated, weighed and their volumes determined by displacement of Medium 199 (Gibco, Grand Island, NY, USA) in a graduated cylinder. A centre slice from each corpus luteum was processed for morphometric analysis of the number and size of steroidogenic and non-steroidogenic luteal cells. Three additional slices were weighed, minced and then homogenized in $0.25 \mathrm{M}$-sucrose $\left(1 \mathrm{ml} / 100 \mathrm{mg}\right.$ tissue) at $4^{\circ} \mathrm{C}$ with a Polytron homogenizer (Brinkman Instruments). Preparations were further homogenized by 25 strokes in a ground-glass homogenizer. Cell debris was removed by consecutive centrifugations at $100 \mathrm{~g}$ for $10 \mathrm{~min}$ at $4^{\circ} \mathrm{C}$ with supernatants from each centrifugation pooled. Luteal homogenates were stored at $-70^{\circ} \mathrm{C}$ until assayed for progesterone (Niswender, 1973). In addition, stored homogenates were further centrifuged $(30000 \mathrm{~g} ; 45 \mathrm{~min})$ to obtain membrane fractions which were suspended in $50 \mathrm{~mm}-$ Tris- $\mathrm{HCl}, \mathrm{pH} 7.2$ with $1 \mathrm{~mm}-\mathrm{CaCl}_{2}$ and $1 \mathrm{~mm}-\mathrm{NaN}_{3}$ buffer and used to assay unoccupied receptors for $\mathrm{LH}$ using the standard curve method (Braden et al., 1986). Following collection of corpora lutea, hypophysectomized cwes were exsanguinated and the sella turcica examined to assess the completeness of the surgical procedure. Any tissue fragments present were fixed and processed for microscopic evaluation.

Experiment II. Based on the results of Exp. I it appeared that the dose of LH used ( $2 \mu \mathrm{g} / 4 \mathrm{~h}$ for 7 days) did not support complete luteal development. Therefore, a second experiment was designed utilizing a dose of $\mathrm{LH}$ which had supported luteal function in hypothalamic-pituitary stalk-disconnected ewes in a previous study (Niswender $e t$ al., 1986). Fourteen ewes exhibiting normal oestrous cycles were randomly assigned to receive: (1) sham hypophysectomy with no LH replacement (Group S-LH; $\mathrm{N}=5$ ); (2) sham hypophysectomy with LH replacement consisting of a $40 \mu \mathrm{g}$ dose of $\mathrm{LH}$ given i.v. at 4-h intervals from Day 5 to Day 12 of the oestrous cycle (Group S $\mathrm{LH} ; \mathrm{N}=5$ ); and (3) hypophysectomy plus $\mathrm{LH}$ replacement therapy administered as in Group $\mathrm{S}+\mathrm{LH}$ (Group $\mathrm{H}+\mathrm{LH}$; $\mathrm{N}=4$ ). Experimental procedures were similar to those described for Exp. I.

Radioimmunoassays. Concentrations of LH were measured in 9 radioimmunoassays (Niswender et al., 1969). Mean sensitivity was $0.11 \mathrm{ng} / \mathrm{ml}$ and intra- and interassay coefficients of variation were $7 \%$ and $17 \%$, respectively. The standards used was NIH-oLH-S24. Concentrations of progesterone in luteal tissue and serum were measured in an assay (Niswender, 1973) with a sensitivity of $0.04 \mathrm{ng} / \mathrm{ml}$ serum and $0.8 \mathrm{ng} / \mathrm{mg}$ tissue and intra- and interassay coefficients of variation of $5 \%$ and $16 \%$, respectively ( $n=5$ assays). Sensitivity of the cortisol assay (Hasler $e t$ al., 1976) was $0.85 \mathrm{ng} / \mathrm{ml}$ with intra- and interassay coefficients of variation of $10 \%$ and $12 \%$, respectively ( $n=2$ assays).

Morphometric analysis. Morphometric analysis of corpora lutea was performed as described by Farin et al. (1986) with the exception that a point-count analysis utilizing a dual-grid system was used to collect primary data. A 56-point grid with an interpoint spacing of $2 \mathrm{~cm}$ was used to determine the volume density of cytoplasm for all cell types as well as the volume density of extracellular matrix and vascular space. All photographs of luteal tissue were printed at $\times 4750$ magnification. Superimposed on the 56-point grid was a 224-point grid with an interpoint spacing of $1 \mathrm{~cm}$ which was used to determine the volume density of nuclei for all cell types. Morphometric estimates obtained by planimetric and point-count procedures were comparable (data not shown). For each corpus luteum, morphometric estimates were based on analysis of a total of $25716 \pm 99 \mu \mathrm{m}^{2}$ luteal tissue.

Statistical analysis. Data regarding pulses of LH in serum were analysed using the PULSAR program (Merriam \& Wachter, 1982). In this program preselected parameters, or G-values, are used to define individual pulses of LH; the G-values selected for the present studies were: (G1) 7.50, (G2) 5.50, (G3) 2.25, (G4) 1.75 and (G5) 1.30. All data were analysed by one-way analysis of variance. When a significant $\mathrm{F}$-statistic was encountered, means were separated using Duncan's procedure. The presence of heterogeneity of variance was evaluated using methods reported by Cochran (1941) and, when encountered, log transformations of the data were performed to remove heterogeneity before the final data analysis.

\section{Results}

\section{Experiment I}

The sella turcica was examined for pituitary fragments at the termination of the experiment and none was found. However, two hormonal criteria were also used to evaluate completeness of hypophysectomy. First, concentrations of cortisol in serum had to be non-detectable within $48 \mathrm{~h}$ 
after surgery and remain so for the duration of the experiment. Secondly, concentrations of LH in serum during the period of frequent bleeding on Day 10 or 11 had to be undetectable. The 6 ewes in Group H-LH were considered to be completely hypophysectomized by both criteria.

Treatment of hypophysectomized ewes with $2 \mu \mathrm{g}$ purified ovine LH at 4-h intervals produced pulses similar in amplitude to endogenous pulses of $\mathbf{L H}$ in control ewes (Table 1). Treatment of Group S+LH ewes with LH did not affect the average height or frequency of LH pulses but significantly increased basal concentrations of $\mathrm{LH}$.

Corpora lutea collected from ewes after hypophysectomy on Day 5 of the oestrous cycle weighed less than corpora lutea from control ewes $(P<0.05$; Table 1). Although treatment of hypophysectomized ewes with LH maintained corpora lutea at an intermediate weight, they remained significantly lighter than controls $(P<0.05$; Table 1$)$. Concentrations of progesterone in serum and luteal tissue were significantly lower in hypophysectomized ewes (Fig. 1, Table 1). Treatment of hypophysectomized ewes with LH maintained concentrations of progesterone in serum and increased $(P<0.05)$ luteal content of progesterone and unoccupied receptors for $\mathrm{LH}$.

Hypophysectomy caused a decrease in the proportion of corpora lutea occupied by small luteal cells and a significant increase in the quantity of unidentifiable other cellular material (Table 1). There was no increase in unidentifiable components in corpora lutea from hypophysectomized ewes which received LH (Table 1). There was an increase $(P<0.05)$ in the volume density of large luteal cells after LH treatment of hypophysectomized ewes.

There were decreased $(P<0.05)$ numbers of small luteal cells after hypophysectomy (Table 1). Treatment with LH after hypophysectomy maintained the number of small luteal cells at an intermediate level compared to controls. In contrast, neither hypophysectomy nor replacement with $\mathbf{L H}$ affected the number of large luteal cells. Both the ratio of small to large luteal cells and the total number of steroidogenic luteal cells were decreased in ewes from the Group $\mathrm{H}-\mathrm{LH}$ compared to Group S-LH $(P<0 \cdot 05 ;$ Table 1$)$. In addition, the number of non-steroidogenic cells was less in hypophysectomized ewes $(P<0.05)$. Treatment with LH maintained numbers of non-steroidogenic cells at an intermediate level in hypophysectomized ewes compared to controls (Table 1). The low weight of corpora lutea from hypophysectomized ewes was associated with losses in the numbers of small luteal cells, fibroblasts and vascular cells (Table 1).

Small and large luteal cells and fibroblasts were significantly smaller in corpora lutea after hypophysectomy (Table 1). In contrast, replacement therapy with LH maintained mean cellular volume and diameter of these cell types at control levels. Treatment of intact ewes with $\mathrm{LH}$ resulted in a significant increase in the volume and diameter of small luteal cells $(P<0.05$; Table 1$)$.

\section{Experiment II}

Circulating concentrations of cortisol were undetectable in the 4 hypophysectomized ewes by $24 \mathrm{~h}$ after surgery (Table 2). Remnants of pituitary tissue were found upon examination of the sella turcica in 3 hypophysectomized ewes at the completion of the experiment. Because no differences were detected in serum values of cortisol between ewes with or without tissue remnants (data not shown), data from all animals were included in the statistical analysis. Pulses of LH in Group S-LH were similar in height and frequency to those seen in Exp. I (Table 2). After administration of a $40 \mu \mathrm{g}$ dose of $\mathrm{LH}$, circulating $\mathrm{LH}$ concentrations varied from 14.1 to $30.8 \mathrm{ng} / \mathrm{ml}$ and remained $>\mathrm{I} \mathrm{ng} / \mathrm{ml}$ for $2-4 \mathrm{~h}$, resulting in higher basal values of $\mathrm{LH}$ (Table 2). No differences due to treatment were detected for the weight of corpora lutea or concentrations of progesterone in serum or tissue $(P>0 \cdot 10$; Table 2$)$. The concentration of unoccupied receptors for LH was less $(P<0 \cdot 10)$ in luteal tissue from both groups of LH-treated ewes than in saline-treated controls.

Steroidogenic cells occupied a greater proportion of corpora lutea in Group H + LH compared to controls $(P<0.05$; Table 2$)$. Treatment with LH was associated with a significant reduction in the volume of extracellular matrix (Table 2). Although there were no significant differences in the numbers of luteal cells with treatment, administration of LH tended to decrease the ratio of small 
Table 1. Results of Exp. I

\begin{tabular}{|c|c|c|c|c|}
\hline & \multicolumn{2}{|c|}{ Sham-hypophysectomized } & \multicolumn{2}{|c|}{ Hypophysectomized } \\
\hline & $-\mathbf{L H}$ & $+\mathrm{LH}$ & $-\mathrm{LH}$ & $+\mathrm{LH}$ \\
\hline No. of ewes & 7 & 7 & 6 & 7 \\
\hline Cortisol (ng/ml) & $10 \cdot 2 \pm 1 \cdot 7$ & $8 \cdot 03 \pm 1 \cdot 0$ & ND* $^{*}$ & ND \\
\hline $\begin{array}{l}\text { Serum LH } \\
\text { Pulses } / 10 \mathrm{~h} \\
\text { Peak }(\mathrm{ng} / \mathrm{ml}) \\
\text { Basal }(\mathrm{ng} / \mathrm{ml})\end{array}$ & $\begin{array}{l}3.71 \pm 0.94 \\
0.60 \pm 0.08 \\
0.12 \pm 0.01^{\mathrm{a}}\end{array}$ & $\begin{array}{l}3.29 \pm 0.57 \\
0.80 \pm 0.22 \\
0.21 \pm 0.03^{\mathrm{b}}\end{array}$ & $\frac{\overline{-}}{0 \cdot 11 \pm 0.03^{\mathrm{a}}}$ & $\begin{array}{l}2.5 \\
0.67 \pm 0.06 \\
0.12 \pm 0.01^{\mathrm{a}}\end{array}$ \\
\hline Luteal weight (mg/CL) & $633 \pm 65^{\mathrm{a}}$ & $664 \pm 41^{a}$ & $164 \pm 32^{c}$ & $394 \pm 14^{b}$ \\
\hline $\begin{array}{l}\text { Luteal progesterone } \\
\mathrm{mg} / \mathrm{CL} \\
\mathrm{ng} / \mathrm{mg}\end{array}$ & $\begin{array}{l}11 \cdot 6 \pm 1 \cdot 8^{\mathrm{a}} \\
18 \cdot 0 \pm 1 \cdot 9^{\mathrm{a}}\end{array}$ & $\begin{array}{l}13 \cdot 5 \pm 2 \cdot 3^{a} \\
20 \cdot 0 \pm 2 \cdot 8^{a}\end{array}$ & $\begin{array}{l}0 \cdot 8 \pm 0 \cdot 4^{\mathrm{c}} \\
4 \cdot 5 \pm 2 \cdot 3^{\mathrm{b}}\end{array}$ & $\begin{array}{r}6 \cdot 5 \pm 1 \cdot 2^{b} \\
16 \cdot 4 \pm 2 \cdot 8^{a}\end{array}$ \\
\hline $\begin{array}{l}\text { Luteal LH receptors } \\
\text { fmol/CL } \\
\text { fmol/mg }\end{array}$ & $\begin{array}{l}566 \pm 108^{a} \\
1.7 \pm 0.8\end{array}$ & $\begin{array}{l}446 \pm 96^{a} \\
0.7 \pm 0 \cdot 2\end{array}$ & $\begin{array}{l}85 \pm 39^{b} \\
0.4 \pm 0 \cdot 2\end{array}$ & $\begin{array}{l}345 \pm 65^{\mathrm{a}} \\
0.9 \pm 0.2\end{array}$ \\
\hline $\begin{array}{l}\text { Steroidogenic } \\
\text { Small luteal } \\
\text { Large luteal }\end{array}$ & $\begin{array}{l}\text { Volume d } \\
50 \pm 2^{\mathrm{a}} \\
25 \pm 3^{\mathrm{a}} \\
26 \pm 2^{\mathrm{a}}\end{array}$ & $\begin{array}{l}\text { of luteal comp } \\
51 \pm 2^{\mathrm{a}} \\
26 \pm 3^{\mathrm{a}} \\
24 \pm 1^{\mathrm{a}}\end{array}$ & $\begin{array}{l}(\%) \\
37 \pm 7^{b} \\
11 \pm 3^{b} \\
26 \pm 4^{a}\end{array}$ & $\begin{array}{l}54 \pm 2^{\mathrm{a}} \\
19 \pm 2^{\mathrm{a}} \\
35 \pm 3^{\mathrm{b}}\end{array}$ \\
\hline Fibroblasts & $11 \pm 2$ & $10 \pm 1$ & $10 \pm 1$ & $9 \pm 1$ \\
\hline $\begin{array}{l}\text { Capillaries } \\
\text { CE/Pt } \\
\text { Lumen }\end{array}$ & $\begin{array}{c}16 \pm 1^{a} \\
14 \pm 1 \\
2 \cdot 5 \pm 0 \cdot 9\end{array}$ & $\begin{array}{l}14 \pm 1^{\mathrm{ab}} \\
11 \pm 1 \\
2 \cdot 6 \pm 0.6\end{array}$ & $\begin{array}{l}11 \pm 1^{b} \\
10 \pm 1 \\
0.9 \pm 0 \cdot 3\end{array}$ & $\begin{array}{l}17 \pm 1^{a} \\
12 \pm 2 \\
1.8 \pm 0.6\end{array}$ \\
\hline Matrix & $21 \pm 2^{\mathrm{ab}}$ & $23 \pm 1^{b}$ & $25 \pm 4^{b}$ & $16 \pm 1^{a}$ \\
\hline Other & $1 \pm 0 \cdot 4^{\mathrm{a}}$ & $3 \pm 1^{2}$ & $15 \pm 4^{b}$ & $5 \pm 1^{\mathrm{a}}$ \\
\hline $\begin{array}{l}\text { Steroidogenic } \\
\text { Small luteal } \\
\text { Large luteal } \\
\text { Small/large ratio }\end{array}$ & $\begin{array}{l}\text { Number of } \\
98 \pm 13^{\mathrm{a}} \\
82 \pm 12^{\mathrm{a}} \\
16 \pm 2 \\
5 \cdot 5 \pm 0 \cdot 9^{\mathrm{a}}\end{array}$ & $\begin{array}{l}\text { er corpus lute } \\
86 \pm 13^{\mathrm{ab}} \\
73 \pm 13^{\mathrm{ab}} \\
13 \pm 1 \\
6 \cdot 0 \pm 1 \cdot 5^{\mathrm{a}}\end{array}$ & $\begin{array}{l}\left.10^{-6}\right) \\
32 \pm 9^{\mathrm{c}} \\
20 \pm 6^{\mathrm{c}} \\
12 \pm 3 \\
2 \cdot 2 \pm 0 \cdot 6^{\mathrm{b}}\end{array}$ & $\begin{array}{l}61 \pm 8^{\mathrm{bc}} \\
46 \pm 6^{\mathrm{bc}} \\
15 \pm 2 \\
3 \cdot 3 \pm 0 \cdot 5^{\mathrm{ab}}\end{array}$ \\
\hline $\begin{array}{l}\text { Non-steroidogenic } \\
\text { Fibroblasts } \\
\text { CE } / \mathrm{P}^{\dagger}\end{array}$ & $\begin{aligned} 212 & \pm 23^{\mathrm{a}} \\
81 & \pm 14^{\mathrm{ab}} \\
131 & \pm 19^{\mathrm{a}}\end{aligned}$ & $\begin{array}{l}199 \pm 19^{\mathrm{a}} \\
85 \pm 9^{\mathrm{a}} \\
114 \pm 13^{\mathrm{ab}}\end{array}$ & $\begin{array}{l}85 \pm 21^{c} \\
41 \pm 8^{c} \\
44 \pm 13^{c}\end{array}$ & $\begin{array}{c}143 \pm 8^{\mathrm{b}} \\
55 \pm 6^{\mathrm{bc}} \\
88 \pm 6^{\mathrm{b}}\end{array}$ \\
\hline Total no. of cells & $311 \pm 33^{a}$ & $285 \pm 29^{a}$ & $117 \pm 29^{c}$ & $203 \pm 15^{b}$ \\
\hline $\begin{array}{l}\text { Steroidogenic cells } \\
\text { Small luteal }\end{array}$ & Lute & olume and dic & & \\
\hline $\begin{array}{l}\text { Volume }\left(10^{3} \mu \mathrm{m}^{3}\right) \\
\text { Diameter }(\mu \mathrm{m})\end{array}$ & $\begin{array}{r}2 \cdot 0 \pm 0 \cdot 2^{\mathrm{a}} \\
15 \cdot 6 \pm 0 \cdot 6^{\mathrm{a}}\end{array}$ & $\begin{array}{r}3 \cdot 3 \pm 0 \cdot 6^{\mathrm{b}} \\
18 \cdot 0 \pm 1 \cdot 0^{\mathrm{b}}\end{array}$ & $\begin{array}{r}1 \cdot 1 \pm 0 \cdot 2^{\mathrm{c}} \\
12 \cdot 6 \pm 0 \cdot 6^{\mathrm{c}}\end{array}$ & $\begin{aligned} & 1 \cdot 8 \pm 0 \cdot 2^{\mathrm{a}} \\
& 15 \cdot 1 \pm 0 \cdot 5^{\mathrm{a}}\end{aligned}$ \\
\hline $\begin{array}{l}\text { Large luteal } \\
\text { Volume }\left(10^{3} \mu \mathrm{m} 3\right) \\
\text { Diameter }(\mu \mathrm{m})\end{array}$ & $\begin{array}{l}10 \cdot 3 \pm 0 \cdot 9^{\mathrm{ab}} \\
26 \cdot 8 \pm 0 \cdot 8^{\mathrm{a}}\end{array}$ & $\begin{array}{l}13 \cdot 8 \pm 1 \cdot 4^{\mathrm{b}} \\
30 \cdot 0 \pm 1 \cdot 0^{\mathrm{a}}\end{array}$ & $\begin{array}{r}6 \cdot 2 \pm 1 \cdot 7^{\mathrm{a}} \\
22 \cdot 1 \pm 1 \cdot 8^{\mathrm{b}}\end{array}$ & $\begin{array}{l}10 \cdot 8 \pm 1 \cdot 5^{\mathrm{b}} \\
27 \cdot 1 \pm 1 \cdot 2^{\mathrm{a}}\end{array}$ \\
\hline $\begin{array}{l}\text { Non-steroidogenic cells } \\
\text { Fibroblasts } \\
\text { Volume }\left(10^{3} \mu \mathrm{m}^{3}\right) \\
\text { Diameter }(\mu \mathrm{m})\end{array}$ & $\begin{array}{r}0.9 \pm 0 \cdot 1^{\mathrm{a}} \\
11 \cdot 7 \pm 0.4^{\mathrm{a}}\end{array}$ & $\begin{array}{r}0 \cdot 9 \pm 0 \cdot 1^{\mathrm{a}} \\
11 \cdot 8 \pm 0 \cdot 4^{\mathrm{a}}\end{array}$ & $\begin{array}{l}0.5 \pm 0.04^{b} \\
9 \cdot 6 \pm 0.3^{b}\end{array}$ & $\begin{array}{r}0 \cdot 7 \pm 0 \cdot 1^{\mathrm{a}} \\
10 \cdot 9 \pm 0 \cdot 3^{\mathrm{a}}\end{array}$ \\
\hline $\begin{array}{l}\text { Endothelial cells/peric } \\
\text { Volume }\left(10^{3} \mu \mathrm{m}^{3}\right) \\
\text { Diameter }(\mu \mathrm{m})\end{array}$ & $\begin{array}{r}0.7 \pm 0 \cdot 1 \\
11 \cdot 1 \pm 0.4\end{array}$ & $\begin{array}{l}0.7 \pm 0.04 \\
11 \cdot 2 \pm 0 \cdot 2\end{array}$ & $\begin{array}{r}0 \cdot 5 \pm 0 \cdot 1 \\
10 \cdot 0 \pm 0 \cdot 3\end{array}$ & $\begin{array}{r}0 \cdot 8 \pm 0 \cdot 1 \\
11 \cdot 0 \pm 0 \cdot 3\end{array}$ \\
\hline
\end{tabular}

Values are mean \pm s.e.m.

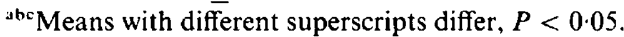

*ND = not detectable.

$\leftarrow \mathrm{CE} / \mathrm{P}=$ capillary endothelial cells and pericytes. 


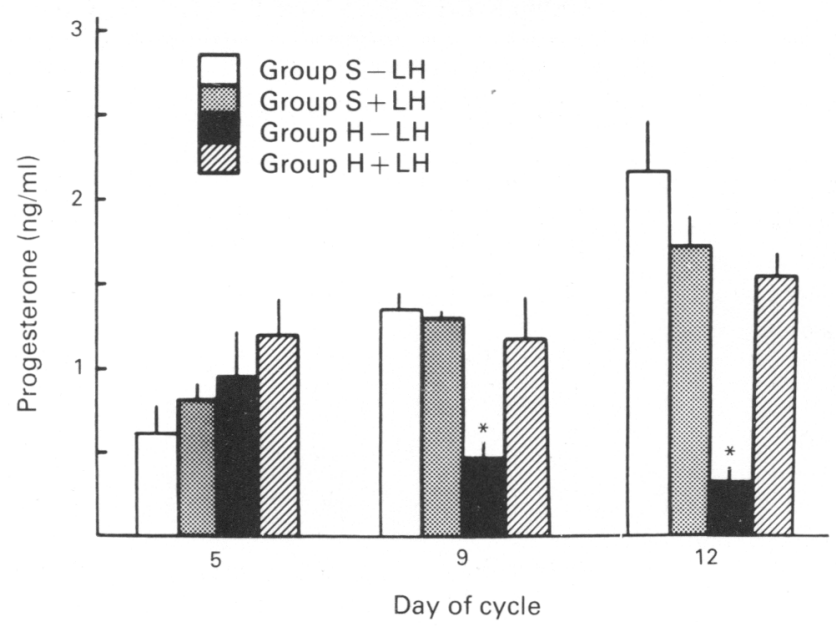

Fig. 1. Effect of treatment on serum concentrations of progesterone (Exp. I). Each bar represents mean \pm s.e.m. ${ }^{*} P<0.05$ compared to Group S $\mathrm{LH}$.

luteal cells to large luteal cells in the ewes in Group S+LH compared to those in Group S-LH or Group H + LH $(P<0 \cdot 10$; Table 2$)$.

Treatment with $40 \mu \mathrm{g} \mathrm{LH}$ was associated with a significant increase in the size of small luteal cells in sham-operated and hypophysectomized ewes ( $P<0.05$; Table 2$)$. Treatment with $40 \mu \mathrm{g} \mathrm{LH}$ did not influence the size of large luteal cells or fibroblasts but had a slight effect on the diameter of endothelial cells/pericytes. Ultrastructurally, luteal tissue from Group H+LH ewes in Exp. II appeared similar to that from controls.

\section{Discussion}

Treatment of hypophysectomized ewes with purified LH to mimic endogenous levels during the luteal phase resulted in maintenance of steroidogenic activity in luteal tissue but did not maintain luteal weight, content of progesterone or total number of cells at control levels. It is possible that similar or slightly larger doses of $\mathrm{LH}$ administered to the hypophysectomized ewes at 3-h rather than 4-h intervals may have maintained luteal weight at normal values since the frequency of $\mathrm{LH}$ pulses in the Group $\mathrm{H}-\mathrm{LH}$ ewes was slightly lower than that of the control ewes. Treatment with doses of LH sufficient to raise circulating concentrations of $\mathrm{LH}$ to at least $14 \mathrm{ng} / \mathrm{ml}$ every $4 \mathrm{~h}$ effectively maintained luteal function and luteal cell numbers.

Differences in luteal weight between ewes in Groups $\mathrm{H}-\mathrm{LH}, \mathrm{S}+\mathrm{LH}$ and S-LH in Exp. I can be accounted for by fewer non-steroidogenic cells coupled with fewer numbers of small luteal cells. These data probably infer a lack of continued normal development of the corpora lutea from Group $\mathrm{H}-\mathrm{LH}$ ewes since the number of small luteal cells at $20 \times 10^{6}$ cells/CL is actually between that found on Day $4\left(10 \times 10^{6}\right.$ cells $\left./ C L\right)$ and Day $8\left(40 \times 10^{6}\right.$ cells/CL) of the oestrous cycle (Farin et al., 1986). In addition, the size of the large luteal cells in Group H-LH corpora lutea $(22 \mu \mathrm{m}$ diameter) was comparable to that found in normal corpora lutea on Day 4 of the oestrous cycle. Treatment of hypophysectomized ewes with a low dose of LH maintained the number of steroidogenic luteal cells but not the number of non-steroidogenic cells. However, even at the low dose of LH used, volume and diameter of steroidogenic and non-steroidogenic luteal cell types increased. This indicates that LH has an important trophic function which affects all luteal cell types. The action of LH on non-steroidogenic luteal cells may be through an indirect mechanism since binding of LH has not been demonstrated in endothelial cells or fibroblasts. Corpora lutea produce fibro- 
Table 2. Results of Exp. II

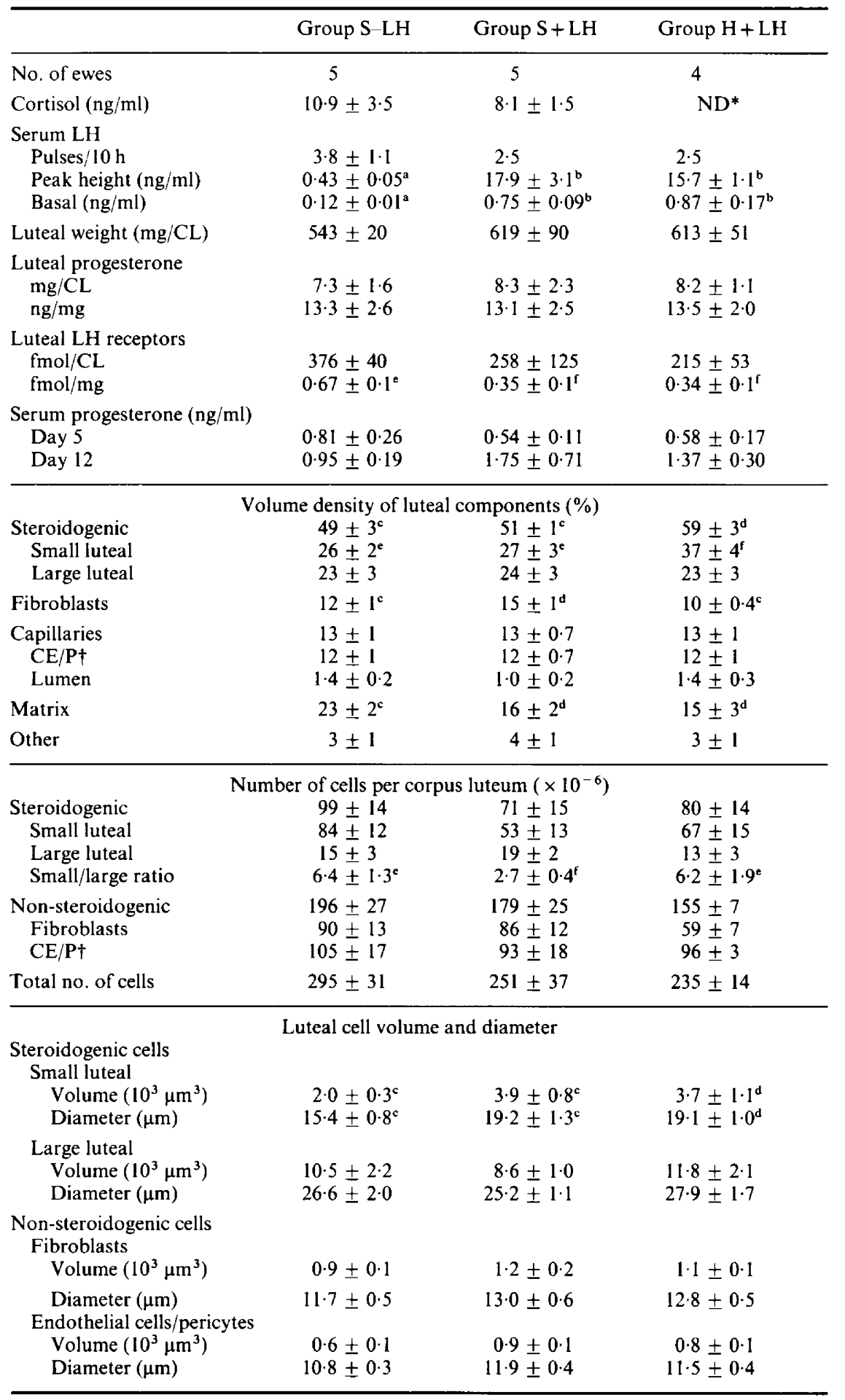

Values are mean \pm s.e.m.

*ND $=$ not detectable.

$+\mathrm{CE} / \mathrm{P}=$ capillary endothelial cells and pericytes.

${ }^{\mathrm{ab}} \mathrm{Means}$ within rows with different superscripts are different, $P<0.01$.

${ }^{\text {cd }}$ Means within rows with different superscripts are different, $P<0.05$.

ef Means within rows with different superscripts are different, $P<0 \cdot 10_{0}$ 
blast growth factor (FGF), a potent angiogenic substance (Jakob et al., 1977; Gospodarowicz \& Thakral, 1978; Gospodarowicz et al., 1985, 1986). In addition, treatment of bovine corpora lutea with $\mathrm{LH}$ in vitro increased the secretion of luteal angiogenic factors (Redmer et al., 1988). Because FGF stimulates mitosis in endothelial cells and fibroblasts, it is possible that decreased production of FGF or other growth/angiogenic factors in ewes in Group L-LH in Exp. I may be responsible for the observed loss of non-steroidogenic luteal cells. We therefore postulate that LH may be acting directly to maintain steroidogenic cell populations and indirectly through its action on steroidogenic luteal cells to support development of non-steroidogenic cell populations.

Elevated concentrations of cortisol have been associated with depression of serum concentrations of both $\mathrm{LH}$ and progesterone and reduction of luteal weight in cattle (Brunner et al., 1969; Wagner et al., 1972; Liptrap \& McNally, 1976; Stoebel \& Moberg, 1979; Matteri \& Moberg, 1982; Li \& Wagner, 1983a, b). Based on in-vitro studies of dispersed bovine pituitary cells, a direct inhibitory action of cortisol on both basal and stimulated release of $\mathrm{LH}$ has been proposed (Li \& Wagner, 1983b). Since elevation of serum concentrations of cortisol will depress pituitary release of $\mathrm{LH}$, it is possible that levels of LH may have been depressed in control ewes in the present studies. However, the levels of cortisol in the Group S-LH and S + LH ewes did not appear to be excessive compared to those associated with $\mathrm{LH}$ suppression as reported for cattle.

We have previously reported that large doses of LH can induce the differentiation of small luteal cells into large luteal cells (Farin et al., 1988). The lower doses of LH used in the present study ( $2 \mu \mathrm{g}$ or $40 \mu \mathrm{g} / 4 \mathrm{~h}$ for 7 days) did not appear to induce differentiation of small into large luteal cells. Rather, administration of LH in these experiments resulted in hypertrophy of small cells. Thus, interconversion of steroidogenic luteal cells may not occur during the mid-luteal phase of the oestrous cycle as a result of exposure to normal pulses of $\mathbf{L H}$.

The results of Exps I and II are inconsistent with reports that purified preparations of LH could not support maintenance of corpora lutea in uterus-intact, hypophysectomized ewes (Kaltenbach et al., 1968; Schroff et al., 1971) or hysterectomized, hypophysectomized ewes (Denamur et al., 1973). The degree of purity for the preparations used in the early studies was far less than that for the LH preparation used in the studies presented herein. It is possible that the procedures used to purify the LH for the early studies could have reduced the biological activity of the preparations, making them ineffective when administered in vivo. In addition, there was no attempt in these early studies to mimic normal luteal phase levels or patterns of LH in serum. Finally, because these early studies were investigating the ability of various pituitary hormone preparations to prevent luteal regression (Kaltenbach et al., 1968) or support the function of aged corpora lutea in the absence of the uterus (Denamur et al., 1973), their results cannot be directly reconciled with those presented here. The results from the present study are consistent with the hypothesis that $\mathrm{LH}$ is the only hypophysial hormone required for the support of luteal development and function in the uterusintact, normally cyclic ewe.

This research was supported by a grant from NIH (HD1 1590). We thank the National Pituitary Hormone Program (NIADD) for generously providing the purified LH used in these studies; Dr H. R. Sawyer for assistance in editing this manuscript; Ms C. Moeller for technical assistance; and Ms K. Miller for help in preparing this manuscript.

\section{References}

Braden, T.D., Manns, J.G., Cermak, D.L., Nett, T.M. \& Niswender, G.D. (1986) Follicular development following parturition and during the estrous cycle in beef cows. Theriogenology 25, 833-843.

Brunner, M.A., Donaldson, L.E. \& Hansel, W. (1969) Exogenous hormones and luteal function in hyster- ectomized and intact heifers. J. Dairy Sci. 52, 1849-1854.

Clarke, I.J., Cummins, J.T. \& de Kretser, D.M. (1983) Pituitary gland function after disconnection from direct hypothalamic influences in the sheep. Neuroendocrinology 36, 376-384. 
Cochran, W.G. (1941) The distribution of the largest of a set of estimated variances as a fraction of their total. Ann. Eugen. 11, 47-52.

Denamur, R., Martinet, J. \& Short, R.V. (1973) Pituitary control of the ovine corpus luteum. J. Reprod. Fert. 32, 207-220.

Farin, C.E., Moeller, C.L., Sawyer, H.R., Gamboni, F. \& Niswender, G.D. (1986) Morphometric analysis of cell types in the ovine corpus luteum throughout the estrous cycle. Biol. Reprod. 35, 1299-1308.

Farin, C.E., Moeller, C.L., Mayan, H., Gamboni, F., Sawyer, H.R. \& Niswender, G.D. (1988) Effect of LH and hCG on cell populations in the ovine corpus luteum. Biol. Reprod. 38, 413-421.

Fitz, T.A., Mayan, M.H., Sawyer, H.R. \& Niswender, G.D. (1982) Characterization of two steroidogenic cell types in the ovine corpus luteum. Biol. Reprod. 27, 703-711.

Gamboni, F., Fitz, T.A., Hoyer, P.B., Wise, M.E., Mayan, M.H. \& Niswender, G.D. (1984) Effect of human chorionic gonadotropin on induced ovine corpora lutea during the anestrous season. Dom. Anim. Endocr. 1, 79-88.

Gospodarowicz, D. \& Thakral, K.K. (1978) Production of a corpus luteum angiogenic factor responsible for proliferation of capillaries and neovascularization of the corpus luteum. Proc. natn. Acad. Sci. USA 75, 847-851.

Gospodarowicz, D., Cheng, J., Lui, G.M., Baird, A., Esch, F. \& Bohlen, P. (1985) Corpus luteum angiogenic factor is related to fibroblast growth factor. Endocrinology 117, 2283-2391.

Gospodarowicz, D., Neufeld, G. \& Schweigerer, L. (1986) Molecular and biological characterization of fibroblast growth factor, an angiogenic factor which also controls the proliferation and differentiation of mesoderm and neuroectoderm derived cells. Cell Differentiation 19, 1-17.

Harrison, L.M., Kenny, N. \& Niswender, G.D. (1987) Progesterone production, LH receptors, and oxytocin secretion by ovine luteal cell types on Days 6, 10 and 15 of the oestrous cycle and Day 25 of pregnancy. J. Reprod. Fert. 79, 539-548.

Hasler, M.J., Painter, K. \& Niswender, G.D. (1976) An ${ }^{125}$ I-labeled cortisol radioimmunoassay in which serum binding proteins are enzymatically denatured. Clin. Chem. 22, 1850-1854.

Hixon, J.E. \& Clegg, M.T. (1969) Influence of the pituitary on ovarian progesterone output in the ewe: effects of hypophysectomy and gonadotropic hormones. Endocrinology 84, 828-834.

Hoyer, P.B. \& Niswender, G.D. (1985) The regulation of steroidogenesis is different in the two types of ovine luteal cells. Can. J. Physiol. Pharmacol. 63, 240-248.

Jakob, W., Jentzsch, B., Bauersberger, B. \& Oehme, P. (1977) Demonstration of angiogenesis activity in the corpus luteum of cattle. Exp. Pathol. 13, 231-236.

Kaltenbach, C.C., Graber, J.W., Niswender, G.D. \& Nalbandov, A.V. (1968) Luteotrophic properties of some pituitary hormones in nonpregnant or pregnant hypophysectomized ewes. Endocrinology 82, 818-824.

Karsch, F.J., Cook, B., Ellicott, A.R., Foster, D.L., Jackson, G.L. \& Nalbandov, A.V. (1971) Failure of infused prolactin to prolong the lifespan of the corpus luteum of the ewe. Endocrinology 89, 272-275.
Li, P.S. \& Wagner, W.C. (1983a) Effects of hyperadrenal states on luteinizing hormone in cattle. Biol. Reprod. 29, 11-24.

Li, P.S. \& Wagner, W.C. (1983b) In vivo and in vitro studies on the effect of adrenocorticotropic hormone or cortisol on the pituitary response to gonadotropin releasing hormone. Biol. Reprod. 29, 25-37.

Liptrap, R.M. \& McNally, P.J. (1976) Steroid concentrations in cows with corticotropin-induced cystic ovarian follicles and the effect of prostaglandin $F_{2 a}$ and indomethacin given by intrauterine injection. Am. J. vet. Res. 37, 369-375.

Matteri, R.L. \& Moberg, G.P. (1982) Effect of cortisol or adrenocorticotrophin on release of luteinizing hormone induced by luteinizing hormone releasing hormone in the dairy heifer. J. Endocr. 92, 141-146.

McClellan, M.C., Diekman, M.A., Abel, J.H., Jr \& Niswender, G.D. (1975) Luteinizing hormone, progesterone and the morphological development of normal and superovulated corpora lutea in sheep. Cell Tiss. Res. 164, 291-307.

McCracken, J.A., Baird, D.T. \& Goding, J.R. (1971) Factors affecting the secretion of steroids from the transplanted ovary of the sheep. Recent Prog. Horm. Res. 27, 537-582.

Merriam, G.R. \& Wachter, K.W. (1982) Algorithms for the study of episodic hormone secretion. Am.J. Physiol. 243 (Endocrinol. Metab. 6), E310-E318.

Niswender, G.D. (1973) Influence of the site of conjugation on the specificity of antibodies to progesterone. Steroids 22, 413-424.

Niswender, G.D. (1974) Influence of 2-br- $\alpha$-ergocryptine on serum levels of prolactin and the estrous cycle in sheep. Endocrinology 94, 612-615.

Niswender, G.D., Reichert, L.E., Jr, Midgley, A.R., Jr \& Nalbandov, A.V. (1969) Radioimmunoassay for bovine and ovine luteinizing hormone. Endocrinology 84, 1166-1173.

Niswender, G.D., Farin, C.E., Gamboni, F., Sawyer, H.R. \& Nett, T.M. (1986) Role of luteinizing hormone in regulating luteal function in ruminants. J. Anim. Sci. 62 (Suppl. 2), 1-14.

O'Shea, J.D., Cran, D.G. \& Hay, M.F. (1979) The small luteal cell of the sheep. J. Anat. 128, 239-25I.

O'Shea, J.D., Cran, D.G. \& Hay, M.F. (1980) Fate of the theca interna following ovulation in the ewe. Cell Tissue Res. 210, 305-319.

Redmer, D.A., Graxul, A.T., Kersch, J.D. \& Reynolds, L.P. (1988) Angiogenic activity of bovine corpora lutea at several stages of luteal development. $J$. Reprod. Fert. 82, 627-634.

Reimers, T.J. \& Niswender, G.D. (1975) Effects of specific neutralization of luteinizing hormone and prolactin on ovarian blood flow and progesterone secretion. In Immunization with Hormones in Reproduction Research, pp. 95-105. Ed. E. Nieschlag. Elsevier, New York.

Rodgers, R.J., O'Shea, J.D. \& Bruce, N.W. (1984) Morphometric analysis of the cellular composition of the ovine corpus luteum. J. Anat. 138, 757-769.

Schroff, C.L. (1971) Identification of the luteotrophic complex in the ewe. Masters thesis, University of Wyoming, Laramie.

Schroff, C.L., Klindt, F.M., Kaltenbach, C.C., Graber, J.W. \& Niswender, G.D. (1971) Maintenance of 
corpora lutea in hypophysectomized ewes. J. Anim. Sci. 33, 268, abstr.

Stoebel, D.P. \& Moberg, G.P. (1979) Effect of ACTH and cortisol on estrous behavior and the luteinizing hormone surge in the cow. Fedn Proc. Fedn Am. Socs exp. Biol. 38, 1254.
Wagner, W.C., Strohbehn, R.E. \& Harris, P.A. (1972) ACTH, corticoids and luteal function in heifers. $J$. Anim. Sci. 34, 789-793.

Warbritton, V. (1934) The cytology of the corpora lutea of the ewe. J. Morph. 56, 181-202.

Received 16 February 1989 